\title{
Effects of nano silver on the growth of banana (Musa spp.) cultured in vitro
}

\author{
Ảnh hưởng của nano bạc lên sự sinh trưởng của cây chuối (Musa spp.) nuôi cấy in vitro
}

DO, Dang Giap*; DANG, Thi Kim Thuy; NGUYEN, Thi Huyen Trang; NGUYEN, Thi Duoc; TRAN, Trong Tuan; DUONG, Duc Hieu

Institute of Tropical Biology, Vietnam Academy of Science and Technology. 9/621 Hanoi highway, Linh Trung ward, Thu Duc district, Ho Chi Minh City, Vietnam

\begin{abstract}
Nano silver has positive effects on the growth and development of in vitro plants. In this study, shoots of in vitro banana with $1 \mathrm{~cm}$ in length were cut off the tip which was cultured in Murashige and Skoog (MS) medium supplemented

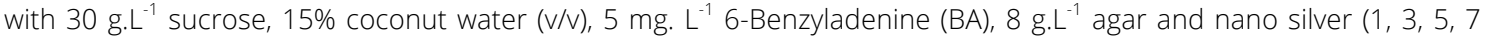
ppm). After twenty days cultured, shoots in the medium supplemented with $1 \mathrm{ppm}$ nano silver have grown well with 8.4 times multiplication and total chlorophyll content $\left(2.05 \mathrm{mg} \cdot \mathrm{g}^{-1}\right)$, three-fold higher than in the control experiment. All new shoot samples were cultivated in a new medium with same component and supplemented with 1 mg. $\mathrm{L}^{-1}$ active charcoal to study root formation. The results showed that the best medium for root development was the one with 3 ppm nano silver. In this treatment, the height of shoots, number of leaves, number of roots, root length, fresh weight, dry weight and total chlorophyll content were $2.90 \mathrm{~cm}, 4.40$ leaves per explant, 7.10 roots per explant, $7.7 \mathrm{~cm}$ per explant, $1.47 \mathrm{~g}$ per explant, $0.136 \mathrm{~g}$ and $3.17 \mathrm{mg} \cdot \mathrm{g}^{-1}$, respectively. In vitro healthy seedlings with equal size were grown in nurseries. Different concentrations of nano silver $(5,10,15 \mathrm{ppm})$ were sprayed on once a week. After 30 days, the highest quality result was observed at concentration $5 \mathrm{ppm}$ with shoot of $4.86 \mathrm{~cm}$ in length, 5.20 leaves per shoot, 4.60 roots per explant, root of $4.87 \mathrm{~cm}$ in length and $3.07 \mathrm{~g}$ per explant in fresh weight.
\end{abstract}

Nano bạc có tác động tích cực lên quá trình sinh trưởng và phát triển của một số loài thực vật nuôi cấy in vitro. Trong nghiên cứu này, chồi non in vitro có chiều cao $1 \mathrm{~cm}$ đã cắt bỏ đỉnh được nuôi cấy trên môi trường MS có bổ sung $30 \mathrm{~g} / \mathrm{L}$ đường, 15\% nước dừa $(V / V), 5$ mg/L BA, 8 g/L agar và nano bạc ở nồng độ 1, 3, 5, 7 ppm. Sau 20 ngày nuôi cấy, mấu cấy phát triển tốt trên môi trường bổ sung nano bạc nồng độ 1 ppm với hệ số nhân chồi 8,4 lần, hàm lượng chlorophyll tổng số đạt 2,05 mg/g, cao gấp ba lần so với mẫu đối chứng. Mẫu cấy được chuyền sang môi trường mới có thành phần tương tự và bổ sung thêm $1 \mathrm{mg} / \mathrm{L}$ than hoạt tính để khảo sát sự tạo rễ. Kết quả cho thấy mẫu cấy trên môi trường có nồng độ nano bac 3 ppm phát triển tốt nhất với chiều cao cây 2,90 cm/mẫu; số lá 4,40/ mẫu; số rễ 7,10/ mẫu; chiều dài rễ $7,7 \mathrm{~cm} / \mathrm{mẫu}$; khối lượng tươi 1,47 g/mẫu, khối lượng khô 0,136 g/mẫu và hàm lượng chlorophyll tổng đạt 3,17 mg/g. Những cây con in vitro phát triển tốt được trồng ngoài vườn ươm. Các dung dịch nano bạc có nồng độ 5, 10, 15 ppm được dùng để phun lên cây 1 lần/ tuần. Sau 30 ngày, kết quả cao nhất ghi nhận ở dung dịch có nồng độ 5 ppm với chiều cao chồi đạt 4,86cm, 5,20 lá/chồi, 4,60 rễ/mẫu, chiều dài rễ đạt 4,87cm và khối lượng tươi đạt 3,07 g/mẫu.

Keywords: chlorophyll content; development; banana; growth; Musa spp.; nano silver

\section{Introduction}

Banana (Musa spp.) belongs to the Musaceae family and is the most widely exported fruit in the world, providing millions of people living in the tropics and subtropics such as a kind of staple food. In terms of gross value of production, banana is ranked fourth, next to rice, wheat and maize in terms of gross value of production. It is grown in around 150 countries worldwide on an area of 4.84 million ha with gross output of 95.6 million tons (Singh et al., 2011). For high quality applications, the development of uninfected plant material through tissue culture has been one of the main research fields during recent years. In vitro banana clonal propagation started in the early of 1970s (Ma and Shii, 1972) and became a normal technique for a wide range of cultivars by the middle of 1980 s (Vuylsteke, 1989; Smith and Drew, 1990). Nowadays, three main procedures have been described for somatic embryogenesis in banana and based on vegetable tissues such as rhizome fragments or leaf bases (Novak et al., 1989), in vitro proliferating meristems (Dhed'a et al., 1991) and immature male inflorescences (Escalant et al., 1994). However, microbial contaminants are the major challenges of in vitro plant propagation during different stages of culture processes such as initiation of callus or subculturing (Omamor et al., 2007). It was reported that 
about $40-60 \%$ of in vitro banana cultures were lost in spite of using mainly reliable, aseptic procedures (Msogoya et al., 2012). Nano silver is a non-toxic material that shows high capabilities against microorganisms e.g. fungus, bacteria, and viruses. This chemical can disadvantageously affect more than 600 microorganisms (Abdi et al., 2008). The recent years of development in nanotechnology have also increased the use of silver nanoparticles (AgNPs) (Luoma, 2008). AgNPs is commonly used as coating for many products such as medical devices, food storage containers, handrails etc. AgNPs is also spun down in fabrics and in some cases as powder for use in shoes (Luoma 2008). The optical and physical properties of AgNPs make it also very useful in medical applications (Winjhoven et al., 2009).

A lot of research on AgNPs has been documented on microbial and animal cells; however, only a few studies were done on plants (Krishnaraj et al., 2012; Monica and Cremonini, 2009). AgNPs increased plants growth process (shoot and root length, leaf area) and biochemical parameters (chlorophyll, carbohydrate and the content of protein, antioxidant enzymes) of Brassica juncea, common bean and corn (Salama, 2012; Sharma et al., 2012). The aim of this paper to evaluate effect of nano silver on banana growth and development.

\section{Materials and methods}

\subsection{Materials}

Shoots of $1.0 \mathrm{~cm}$ in length having one pair of leaf from in vitro cultured banana cultured at Plant Cell Technology Department, Institute of Tropical Biology were used in this study.

PVP-coated Ag nanoparticles were purchased as a nanosilver colloid (Institute of Material Science, Ho Chi Minh city). AgNP were roughly spherical. The size distribution was as mean 25 - $30 \mathrm{~nm}$. A dilution in deionized water was prepared to make a 1000 ppm Ag stock solution.

\subsection{Culture media}

Shoot multiplication medium was MS basal medium (Murashige and Skoog, 1962) and was modified by Do et al. (2012). MS basal medium was supplemented with $30 \mathrm{~g} / \mathrm{l}$ sucrose, $8 \mathrm{~g} / \mathrm{l}$ agar, $5 \mathrm{mg} / \mathrm{l}$ 6-Benzyladenine (BA) (Duchefa Biochemie, Netherlands), 15\% coconut water (v/v) and different concentrations of nano silver $(0,1,3,5,7$ ppm). Rooting medium was the same composition of shoot multiplication medium and supplemented with $1 \mathrm{mg} / \mathrm{l}$ activated carbon. The $\mathrm{pH}$ of the two media was adjusted to $5.7-$ 5.8 with $0.1 \mathrm{~N} \mathrm{HCl}$ or $\mathrm{KOH}$ before adding $0.8 \%$ agar and autoclaved at $121^{\circ} \mathrm{C}, 1 \mathrm{~atm}$ for 15 minutes.

\subsection{Experimental design}

\subsubsection{Effect of nano silver concentrations on shoot multiplication of in vitro banana}

Shoot of in vitro banana with $1 \mathrm{~cm}$ in length was cut off the tip and the rest of its size $3-5 \mathrm{~mm}$. Then, explants were cultured into the above shoot multiplication medium. The study was carried out to evaluate the effect of different concentrations of nano silver on shoot formation and development of in vitro banana.

After 20 days of culture, shoot multiplication was evaluated by the number of shoots/explant, shoot length (cm), number of leaves/shoot, fresh weight (g/explant), dry weight (g/explant), and total chlorophyll content (mg/g).

\subsubsection{Effect of nano silver concentrations on root formation in vitro banana}

After 20 days of culture, shoots were separated and subcultured on rooting medium. The effect of various concentrations of nano silver on root formation and development of in vitro banana was evaluated by number of leaves/plantlet, number of roots/plantlet, root length (cm), shoot length $(\mathrm{cm})$, fresh weight (g/plantlet), dry weight ( $\mathrm{g} /$ plantlet), total chlorophyll content (mg/g). These parameters were recorded after 20 days of culture.

\subsubsection{Effect of nano silver concentrations on growth and development of ex vitro banana}

Rooted plantlets were removed from the medium, washed under running tap water to remove the agar and planted in a fiber coconut - coal ashes mixture (1:2). The plantlets were watered two times/day by nano silver solutions with different concentrations $(0,5,10,15$ ppm) and watered one time/week. The aim of this experiment was to evaluate the effect of nano silver on growth and development of ex vitro banana.

The data was recorded after 30 days of cultivation with parameters such as the number of leaves/plantlet, number of roots/plantlet, root length $(\mathrm{cm})$, shoot length (cm/plantlet), fresh weight (g/plantlet).

\subsection{Culture condition}

The cultures were maintained at $25 \pm 2^{\circ} \mathrm{C}, 70-80 \%$ air humidity under continuous illumination of $18.70 \pm 1.00$ umol $\mathrm{m}^{-2} \mathrm{~s}^{-1}$ during $12 \mathrm{~h} /$ day provided by fluorescent lamps (Do et al., 2012).

\subsection{Statistical analysis}

The experiments had completely randomized design and were repeated three times with each treatment containing ten explants. The data obtained from the experiments were analysed, calculated and compared by using Dun- 
can's multiple-range test at a 5\% level of significance by SPSS software version 16.0 (Duncan, 1955).

\section{Results and discussion}

\subsection{Effect of nano silver concentrations on shoot multiplication of in vitro banana}

When AgNPs was added into the cultivation medium, the response was positive not only on shoot initiation, number and growth rate but also increased leaf number and total chlorophyll content (Table 1). All shoot multiplication media supplemented with AgNPs (except 7 ppm) led to higher values than the control experiment. The explants on medium with $1 \mathrm{ppm}$ nano AgNPs gained the maximum number of shoots (8.40), highest shoot length $(2.45 \mathrm{~cm})$, maximum number of leaves (12.10) and highest rate fresh weight/dry weight (2.24/0.20 g). These parameters were
1.5 - 2 folds higher than those of explants cultured on medium without nano silver, especially, total chlorophyll

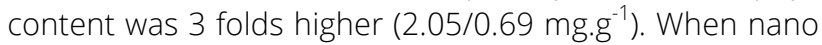
silver solution was increased to 3, 5 and 7 ppm, the parameters began to decrease; particularly, the explants on medium containing 7 ppm developed less than the control but the total chlorophyll content $\left(1.24 \mathrm{mg}^{-\mathrm{g}^{-1}}\right)$ was more than control $\left(0.69 \mathrm{mg} \cdot \mathrm{g}^{-1}\right)$. In the medium with concentrations of 3 and 5 ppm, the number of shoots per explant were $1.4-1.6$ folds higher and the total chlorophyll content was $2.3-2.4$ folds higher compared to control (without nano silver). However, the data recorded in $\mathrm{SH} 2$ and $\mathrm{SH} 3$ treatment was no significantly different between experiments ( $p$ 0.05). In brief, in shoot multiplication medium, the concentration of 1 ppm nano silver was found to be the optimum concentration required to induce maximum shoot growth.

Table 1. Effect of nano silver on multiple shoot formation from cultured shoot tip explants for 20 days

\begin{tabular}{llllllll} 
Treatment & $\begin{array}{l}\text { Concentration of } \\
\text { nano silver } \\
\text { solution (ppm) }\end{array}$ & $\begin{array}{l}\text { No. of } \\
\text { shoots/ } \\
\text { explant }\end{array}$ & $\begin{array}{l}\text { Shoot } \\
\text { length } \\
(\mathrm{cm})\end{array}$ & $\begin{array}{l}\text { No. of } \\
\text { leaves/ } \\
\text { shoots }\end{array}$ & $\begin{array}{l}\text { Fresh } \\
\text { weight } \\
\text { (g/shoots) }\end{array}$ & $\begin{array}{l}\text { Dry } \\
\text { weight } \\
\text { (g/shoots) }\end{array}$ & $\begin{array}{l}\text { Total } \\
\text { chlorophyll } \\
\text { content (mg/g) }\end{array}$ \\
\hline SH0 & 0 & $4.30^{c}$ & $1.67^{c d}$ & $6.73^{c}$ & $1.42^{b}$ & $0.12^{b}$ & $0.69^{c}$ \\
SH1 & 1 & $8.40^{a}$ & $2.45^{a}$ & $12.10^{a}$ & $2.24^{a}$ & $0.20^{a}$ & $2.05^{a}$ \\
SH2 & 3 & $6.80^{b}$ & $2.08^{b}$ & $9.00^{b}$ & $1.73^{b}$ & $0.15^{b}$ & $1.60^{\text {bb }}$ \\
SH3 & 5 & $6.03^{b}$ & $1.80^{c d}$ & $7.40^{c}$ & $1.67^{b}$ & $0.14^{b}$ & $1.65^{a b}$ \\
SH4 & 7 & $4.90^{c}$ & $1.50^{d}$ & $6.76^{c}$ & $1.51^{c}$ & $0.13^{b}$ & $1.24^{b}$
\end{tabular}

Mean values followed by the same letter(s) within a column are not significantly different $(P<0.05)$

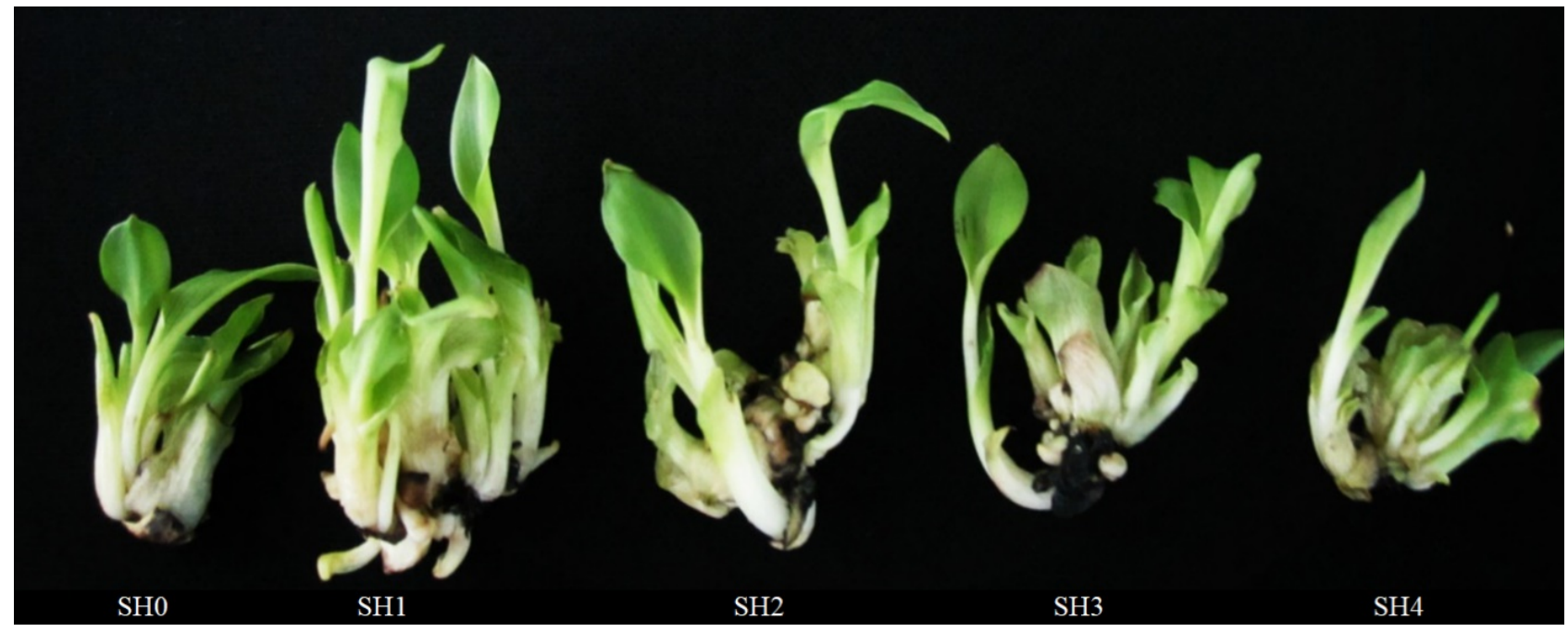

Figure 1. Banana shoots on medium containing different concentrations of nano silver solution after 20 days incubated in vitro (SH0: 0 ppm; SH1: 1 ppm; SH2: 3 ppm; SH3: 5 ppm; SH4: 7 ppm)

\subsection{Effect of nano silver concentrations on root formation of in vitro banana}

Nano silver not only induced shoot multiplication but also influenced root formation of explant (Table 2). More roots were produced in explants inoculated on medium containing nano silver solution in concentrations from 1 to 5 ppm. It was also observed that in vitro shoot cultures on medium containing 3 ppm AgNPs produced maximum number of roots (7.10) per explant with higher root length $(7.70 \mathrm{~cm})$. The highest shoot length $(2.90 \mathrm{~cm})$ and number of leaves per shoot (4.40) was obtained on the medium containing of $3 \mathrm{ppm}$ AgNPs. Fresh weight/dry weight $(1.47 / 0.136 \mathrm{~g})$ with total chlorophyll content $3.17 \mathrm{mg} \cdot \mathrm{g}^{-1}$ was also higher than other treatments. However, these parameters were no significantly different between the R2 and R1 treatment experiments ( $p<0.05)$. When concentration of nano silver solution was increased to $7 \mathrm{ppm}$, 
the growth of shoot was limited. The parameters of growth were lower than control experiment. Nevertheless, the content of chlorophyll in the control experiment
(2.80 $\left.\mathrm{mg} \cdot \mathrm{g}^{-1}\right)$ was still higher than the treatment experiment $\left(2.62 \mathrm{mg} \cdot \mathrm{g}^{-1}\right)$.

Table 2. Effect of nano silver concentrations on rooting medium of in vitro banana after 20 days of incubation

\begin{tabular}{|c|c|c|c|c|c|c|c|c|}
\hline $\begin{array}{l}\text { Treat- } \\
\text { ment }\end{array}$ & $\begin{array}{l}\text { Concentration } \\
\text { of nano silver } \\
\text { solution (ppm) }\end{array}$ & $\begin{array}{l}\text { Shoot } \\
\text { length } \\
(\mathrm{cm})\end{array}$ & $\begin{array}{l}\text { No. of } \\
\text { leaves/ } \\
\text { plantlet }\end{array}$ & $\begin{array}{l}\text { No. of } \\
\text { roots/ } \\
\text { plantlet }\end{array}$ & $\begin{array}{l}\text { Root } \\
\text { length } \\
(\mathrm{cm}) \\
\end{array}$ & $\begin{array}{l}\text { Fresh } \\
\text { weight } \\
\text { (g/plantlet) }\end{array}$ & $\begin{array}{l}\text { Dry } \\
\text { weight } \\
\text { (g/plantlet) }\end{array}$ & $\begin{array}{l}\text { Total } \\
\text { chlorophyll con- } \\
\text { tent (mg/g) }\end{array}$ \\
\hline RO & 0 & $2.30^{\mathrm{bc}}$ & $4.00^{a b}$ & $5.90^{\mathrm{bc}}$ & $5.97^{b c}$ & $1.05^{\mathrm{b}}$ & $0.093^{b}$ & $2.62^{b c}$ \\
\hline R1 & 1 & $2.68^{\mathrm{ab}}$ & $3.90^{\mathrm{ab}}$ & $6.60^{\mathrm{ab}}$ & $6.90^{\mathrm{ab}}$ & $1.15^{b}$ & $0.098^{b}$ & $2.91^{\mathrm{ab}}$ \\
\hline R2 & 3 & $2.90^{a}$ & $4.40^{a}$ & $7.10^{a}$ & $7.70^{a}$ & $1.47^{\mathrm{a}}$ & $0.136^{a}$ & $3.17^{a}$ \\
\hline R3 & 5 & $2.51^{\mathrm{abc}}$ & $3.56^{b}$ & $5.40^{c}$ & $6.04^{b c}$ & $1.09^{b}$ & $0.094^{b}$ & $2.56^{c}$ \\
\hline R4 & 7 & $2.22^{c}$ & $3.41^{b}$ & $5.09^{c}$ & $5.10^{c}$ & $0.71^{c}$ & $0.061^{c}$ & $2.80^{\mathrm{bc}}$ \\
\hline
\end{tabular}

Mean values followed by the same letter(s) within a column are not significantly different $(P<0.05)$

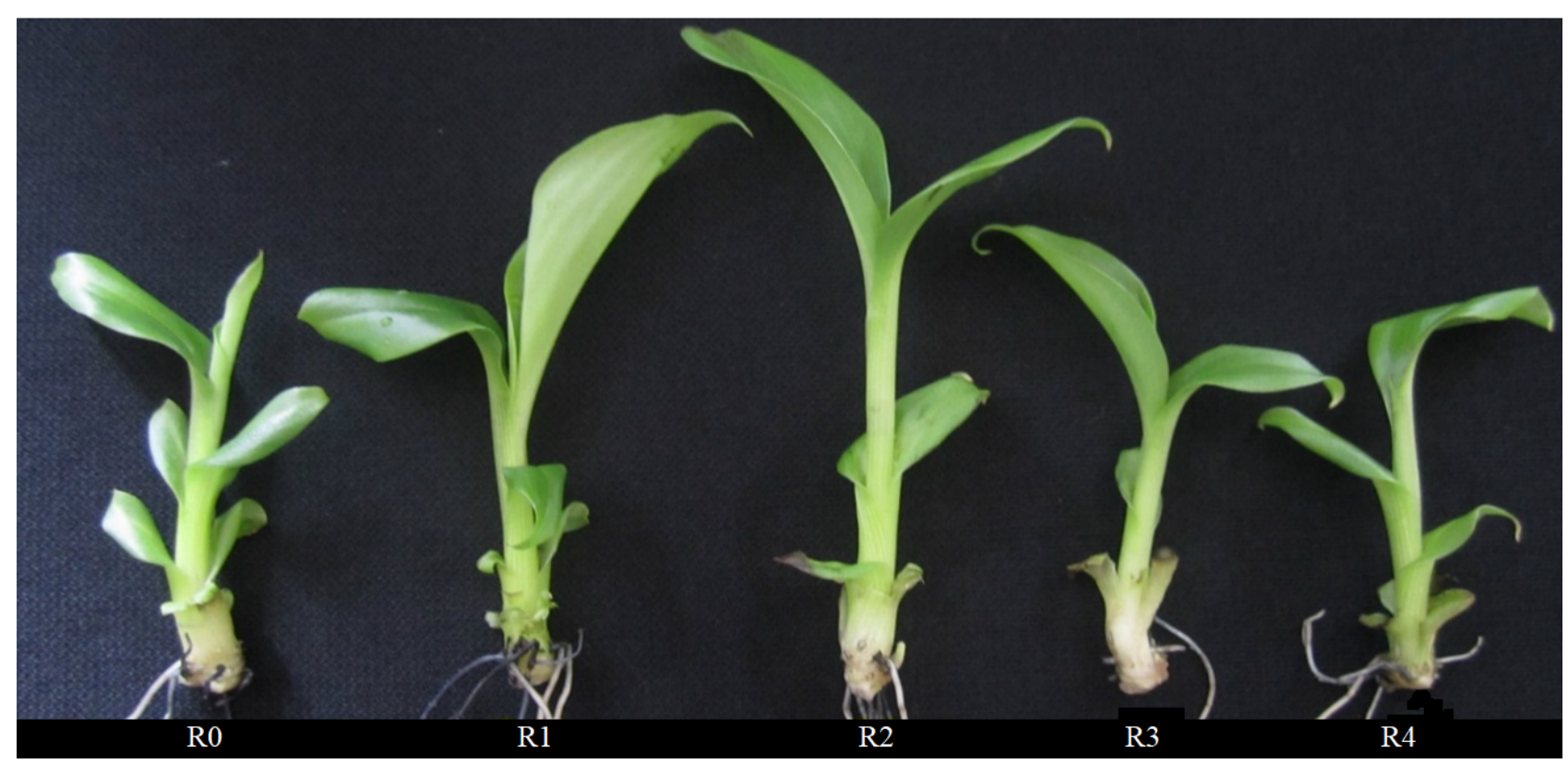

Figure 2. Banana plantlets on rooting medium containing different concentrations of nano silver solution after 20 days incubated in vitro (R0: 0 ppm; R1: 1 ppm; R2: 3 ppm; R3: 5 ppm; R4: 7 ppm)

\subsection{Effect of nano silver concentrations on growth and development of ex vitro banana}

The plantlets in vitro were planted and tended in arboretum. The results were recorded after 30 days' cultivation (Table 3). The plantlets were watered with concentrations of AgNPs from 0 to 5 ppm. N1 treatment experiment exposed effectively growth and development, and a signifi- cant difference ( $p<0.05$ ) among the concentrations tested. The plantlets watered with solution containing $5 \mathrm{ppm}$ AgNPs achieved the highest values of shoot length (4.86 $\mathrm{cm})$, number of leaves per shoot (5.20), number of roots (4.60), root length (4.87), fresh weight (3.07). When concentration of AgNPs was increased, the parameters decreased, at 15 ppm AgNPs being even lower than the control experiment.

Table 3. Effect of nano silver concentrations on growth and development of ex vitro banana at nursery garden after 30 days of cultivation

\begin{tabular}{lllllll} 
Treatment & $\begin{array}{l}\text { Concentration } \\
\text { of AgNPs } \\
\text { (ppm) }\end{array}$ & $\begin{array}{l}\text { Shoot } \\
\text { length } \\
\text { (cm/plantlet) }\end{array}$ & $\begin{array}{l}\text { No. of } \\
\text { leaves/ } \\
\text { plantlet }\end{array}$ & $\begin{array}{l}\text { No. of } \\
\text { roots/ } \\
\text { plantlet }\end{array}$ & $\begin{array}{l}\text { Root } \\
\text { length } \\
\text { (cm) }\end{array}$ & $\begin{array}{l}\text { Fresh } \\
\text { weight } \\
\text { (g/plantlet) }\end{array}$ \\
\hline N0 & 0 & $3.58^{b}$ & $3.50^{d}$ & $3.36^{c}$ & $3.64^{a}$ & $2.49^{b c}$ \\
N1 & 5 & $4.86^{a}$ & $5.20^{a}$ & $4.60^{a}$ & $4.87^{c}$ & $3.07^{a}$ \\
N2 & 10 & $3.60^{b}$ & $4.77^{b}$ & $4.06^{b}$ & $4.10^{b}$ & $2.65^{b}$ \\
N3 & 15 & $3.40^{b}$ & $4.10^{c}$ & $3.53^{c}$ & $3.70^{a}$ & $2.39^{c}$
\end{tabular}

Mean values followed by the same letter(s) within a column are not significantly different $(P<0.05)$ 


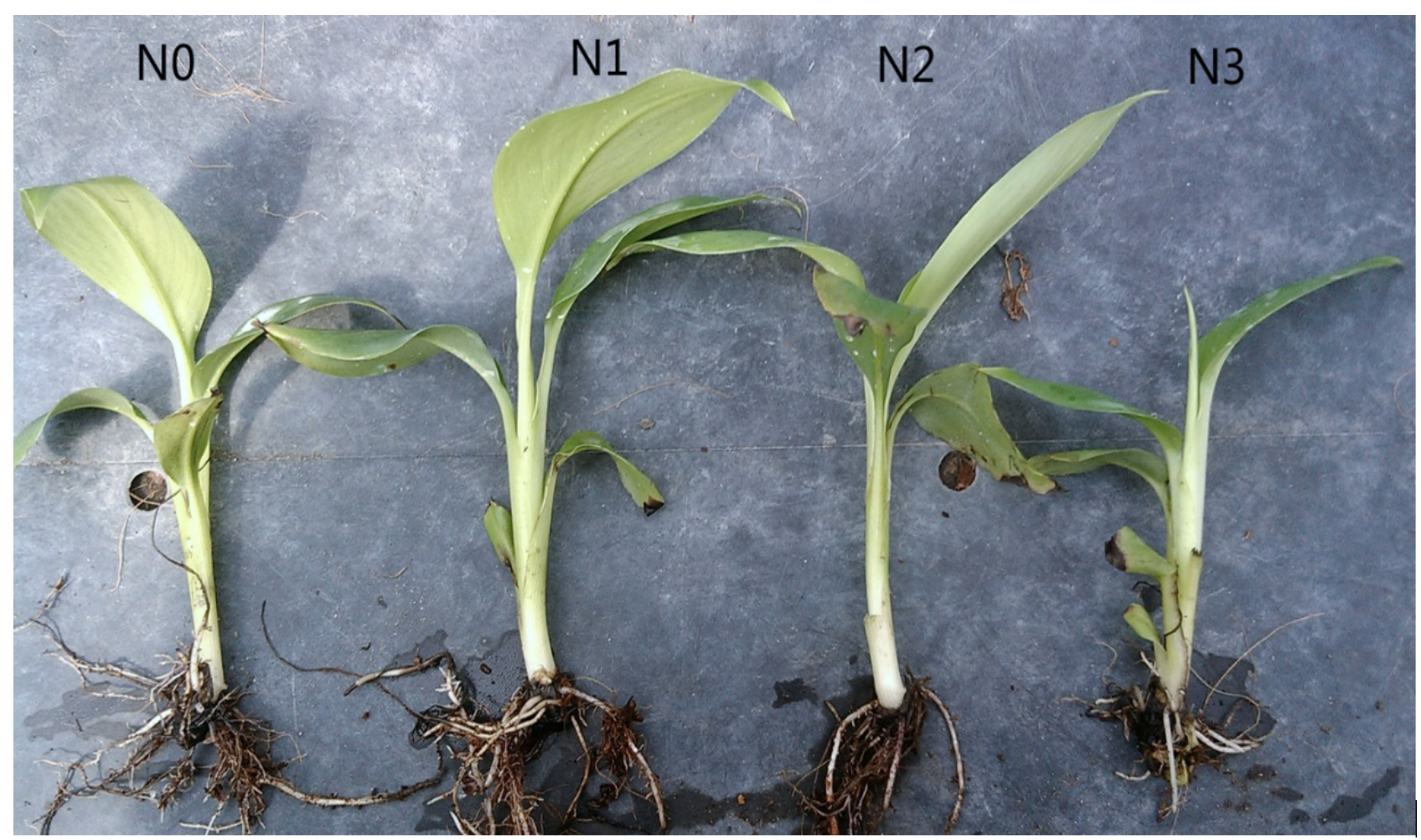

Figure 3. Banana plants were watered with different concentrations of nano silver solution after 30 days at nursery garden (N0: 0 ppm; N1: 5 ppm; N2: 10 ppm; N3: 15 ppm)

\section{Discussion}

AgNPs have positive effects on growth and development of banana plants. The explants were cultured on shoot multiplication medium and rooting medium supplemented with 1 ppm and 3 ppm AgNPs, respectively. These media were optimum for formation and development of shoot and root. Particularly, the chlorophyll content of shoots cultured on medium containing AgNPs was higher than the control experiment (without AgNPs). Salama (2012) and Sharma et al. (2012) reported that AgNPs increased plant growth process (shoot and root length, area of the leaf) and biochemical parameters (chlorophyll, carbohydrate and the content of protein, antioxidant enzymes) of common bean and corn.

Salama (2012) reported that low concentrations of silver nanoparticles had a stimulating effect on the growth of the plantlets, while the enhanced concentrations induced an inhibitory effect. However, the increase in the concentration of silver nanoparticles from 20 to $60 \mathrm{ppm}$ led to an increase in shoot and root lengths, leaf surface area, chlorophyll, carbohydrate and protein contents of the two tested crop plants (Phaseolus vulgaris L. and Zea mays L.).

Sharma et al. (2012) investigated the effect of silver nano particles (at 0, 25, 50, 100, 200 and 400 ppm) on the growth and antioxidant status of 7-day old Brassica juncea seedlings. The results showed that fresh weight, root and shoot length and vigor index of seedlings is positively affected by silver nanoparticle. It induced a 326\% increase in root length and $133 \%$ increase in vigor index of the treated seedlings. The photosynthetic quantum efficiency is improved and the content of chlorophyll in leaves of treated seedlings is recorded higher than the control seedlings.

Nano silver was used with optimum concentration that had a significant effect on the plant shoot, the number of leaves, the height of the plant, plant dry weight, inflorescence dry weight, seed yield, weight of one hundred seeds, polyphenol and tannin content in shoot. The concentration of nano silver from 20 to $60 \mathrm{ppm}$ has led to an improvement in the seed yield (Seif et al., 2011). AgNPs induce root growth by blocking ethylene signalling in Crocus sativus (Rezvani et al. 2012). Silver ions can displace copper ions from the receptor proteins and play an important role in ethylene binding upon receptors.

The effect of peptone and silver nitrate on in vitro shoot formation in Hevea brasiliensis Muell Arg was studied by Yupaporn and Sompong (2012). The addition of silver nitrate in the induction medium at concentrations ranging from 0.5 to $2 \mathrm{mg} / \mathrm{l}$ was successful in promoting shoot multiplication in all the explants with an average number of 5 shoots per explant. In addition, silver nitrate provides silver ions which may interact with polyamines, leading to the promotion of organogenesis and embryogenesis (Zhang et al., 2001).

\section{Conclusion}

Culture medium supplemented with $1 \mathrm{ppm}$ nano silver was the best one for shoot multiplication. After twenty days cultured, shoots in this medium have grown well with 8.4 times multiplication and total chlorophyll content 
(2.05 mg. g-1) was three-fold higher than in the control. The suitable medium for rooting was the one added 3 ppm nano silver. In this treatment, the height of shoots, number of leaves, number of roots, root length, fresh weight, dry weight and total chlorophyll content were 2.90 cm, 4.40 leaves per explant, 7.10 roots per explant, 7.7 cm per explant, $1.47 \mathrm{~g}$ per explant, $0.136 \mathrm{~g}$ and 3.17 $\mathrm{mg} / \mathrm{g}$, respectively. When the plantlets were planted and tended at the arboretum, nano silver also exposed effectively on growth and development of plant when using 5 ppm of concentration. After 30 days, the plant achieved the highest quality with shoot of $4.86 \mathrm{~cm}$ in length, 5.20 leaves per shoot, 4.60 roots per explant, root of $4.87 \mathrm{~cm}$ in length and $3.07 \mathrm{~g}$ per explant in fresh weight.

Acknowledgement: The authors are grateful to the Southern Region National Key Laboratory of Plant Cell Technology - Institute of Tropical Biology, Vietnam Academy of Science and Technology for the financial support to carry out the present experiment.

\section{References}

[1] Abdi, G., Salehi, H. and Khosh-khuri, M. (2008). Nano silver: A novel nanomaterial for removal of Bacterial contamination in Valerian ( $\mathrm{V}$. officinalis) tissue culture. Acta Physiol Plant. 30: 709-714.

[2] Do, D.G, Pham, N.V, Tran, T.T, Nguyen, T.H.T, Pham, N.A.T, Thai, X.D. (2012). "High-frequency shoot multiplication of laba banana (Musa sp.) cultured in vitro by using light, myo-inositol and adenin sulphate". Journal of Biology. 34(3SE): 180-187 (in Vietnamese with English summary).

[3] Dhed' A, D., Dumortier, F., Panis, B., Vuylsteke, D. and De Langhe, E. (1991). Plant regeneration in cell suspension cultures of the cooking banana cultivar 'Bluggoe' (Musa spp. ABB group). Fruits. 46: 125-135.

[4] Duncan, D.B. (1955). Multiple range and multiple F tests. Biometrics. 11(1): 1-5.

[5] Escalant, J.V., Teisson, C. and Cote, F. (1994). Amplified somatic embryogenesis from male flowers of triploid banana and plantain cultivars (Musa spp.). In vitro Cellular Developmental Biology. 30P: 181-186.

[6] Krishnaraj, C., Jagan, E.G., Ramachandran, R., Abirami, S.M., Mohan, N. and Kalaichelvan, P.T. (2012). Effect of biologically synthesized silver nanoparticles on Bacopa monnieri (Linn.) Wettst. Plant growth metabolism. Process Biochem 47(4): 51-658.

[7] Luoma, N.S. (2008). Silvernanotechnologies and the environment: Old problems or new challenges? The Project on Emerging Nanotechnologies. Vol. 15. September 2008.

[8] Ma, S.S. and Shii, C.T. (1972). In vitro formation of adventitious buds in banana shoot apex following decapitation. Journal of Chinese Society for Horticultural Science. 18: 135-142.
[9] Monica, R.C. and Cremonini, R. (2009). Nanoparticles and higher plants. Caryologia. 62(2): 161-165.

[10] Msogoya, T., Kayagha, H., Mutigitu, J., Kulebelwa, M. and Mamiro, M. (2012). Identification and management of microbial contaminants of banana in vitro cultures. J Appl Biol. 55: 3987-3994.

[11] Murashige, T. and Skoog F. (1962). A revised medium for rapid growth and Bio-assays with tobacco tissue cultures. Phys. Plant. 15: 473-497.

[12] Novak, F.J., Afza, R., Van Duren, M., Perea-Dallos, M., Conger, B.V. and Tang, X. (1989). Somatic embryogenesis and plant regeneration in suspension cultures of dessert (AA or AAA) and cooking (ABB) bananas (Musa spp.). Nature Biotechnology. 7: 154159.

[13] Omamor, I.B., Asemota, A.O., Eke, C.R. and Eziashi, E.I. (2007). Fungal contaminants of the oil palm tissue culture in Nigerian Institute for oil palm Research (NIFOR). Afr J Agric Res. 2(10): 534-537.

[14] Rezvani, N., Sorooshzadeh, A. and Farhadi, N. (2012). Effect of nano-silver on growth of saffron in flooding stress. World Acad. Sci. Eng. Technol. 1: 517-522.

[15] Salama, H.M.H. (2012). Effects of silver nanoparticles in some crop plants, common bean (Phaseolus vulgaris L.) and corn (Zea mays L.). Int Res J Biotech. 3(10): 190-197.

[16] Seif, S.M., Sorooshzadeh, A.H., Rezazadeh, S. and Naghdibadi, H.A. (2011). Effect of nano-silver and silver nitrate on seed yield of borage. Journal of Medicinal Plants Research. 5(5): 706-710.

[17] Sharma, P., Bhatt, D., Zaidi, M.G., Saradhi, P.P., Khanna, P.K., Arora, S. (2012). Silver nanoparticlemediated enhancement in growth and antioxidant status of Brassica juncea. Appl Biochem Biotechnol. 167: 2225-2233.

[18] Singh, H., Uma, S., Selvarajan, R. and Karihaloo, J. (2011). Micropropagation for production of quality banana planting material in Asia-Pacific. Asia-Pacific Consortium on Agricultural Biotechnology (APCOAB), New Delhi, India, 92 p.

[19] Smith, M.K. and Drew, R.A. (1990). Current applications of tissue culture in plant propagation and improvement". Australian Journal of Plant Physiology. 17: 267-289.

[20] Vuylsteke, D.K. (1989). Shoot - tip culture for the propagation, conservation and exchange of Musa germplasm. In: Withers LA, ed. "Practical Manuals for Handling Crop Germplasm in vitro". Vol. 2, Rome: IBPGR: 1-56.

[21] Winjhoven, W.P S., Peinenburg, J.G.M W., Herberts, A. C., Hagens I. W., Oomen, G. A., Heugens, H.W. E., Roszek, B., Bisshops, J., Gosens, I., Van De Meent, D., Dekkers, S., De Jong, H. W., Van Zijverden, M., Sips, 
J.A.M A. and Geersma, E. R. (2009). Nano-Silver- a review of available data and knowledge gaps in human and environmental risk assessment. Nanotoxicology. 3(2): 109-138.

[22] Yupaporn, S. and Sompong, T. (2012). The effect of peptone and silver nitrate on in vitro shoot for- mation in Hevea brasiliensis Muell Arg. Journal of Agricultural Technology. 8(4): 1509-1516.

[23] Zhang, P., Phansiri, S. and Puonti, K.J. (2001). Improvements of cassava shoot organogenesis by the use of silver nitrate in vitro. Plant Cell, Tissue and Organ Culture. 67: 47-54. 